ADALAH : Buletin Hukum \&

Keadilan

Buletin Hukum \& Keadilan

@adalahuinjkt

\title{
Partisipasi Publik Dalam Amandemen UUD
}

\author{
Siti Nurhalimah*
}

Pasca runtuhnya rezim orde baru hingga saat ini, semangat amandemen UUD 1945 masih marak disuarakan masyarakat. Semangat tersebut tumbuh karena terdapat berbagai kekurangan dalam UUD 1945 yang dianggap tidak sejalan dengan cita-cita bangsa. Namun dari keempat amandemen UUD 1945 yang telah berlangsung tersebut, tidak ada satu pun yang melibatkan partisipasi rakyat. Sehingga, mimpi bangsa Indonesia untuk memiliki konstitusi ideal berdasarkan Pancasila, belum juga menjadi nyata. (Yunus, 2015: 160).

Banyak dari kalangan ahli Hukum Tata Negara mengatakan, konstitusi di Indonesia yang telah berulang kali mengalami perubahan hasilnya masih belum maksimal. Hal tersebut disebabkan karena perubahannya hanya disesuaikan dengan selera pemerintahan yang berkuasa pada masanya, tanpa disesuaikan dengan prinsip-prinsip negara yang terkandung dalam Pancasila. Sehingga, sudah menjadi hal yang mutlak bahwa dalam mengubah konstitusi harus melibatkan partisipasi aktif dari masyarakat. Marwan Maas dalam jurnalnya menyatakan:

"Dalam melakukan perubahan komprehensif, prosesnya harus melibatkan partisipasi rakyat secara luas agar menghasilkan solusi emansipatoris. Empat kali perubahan UUD 1945 lebih cenderung

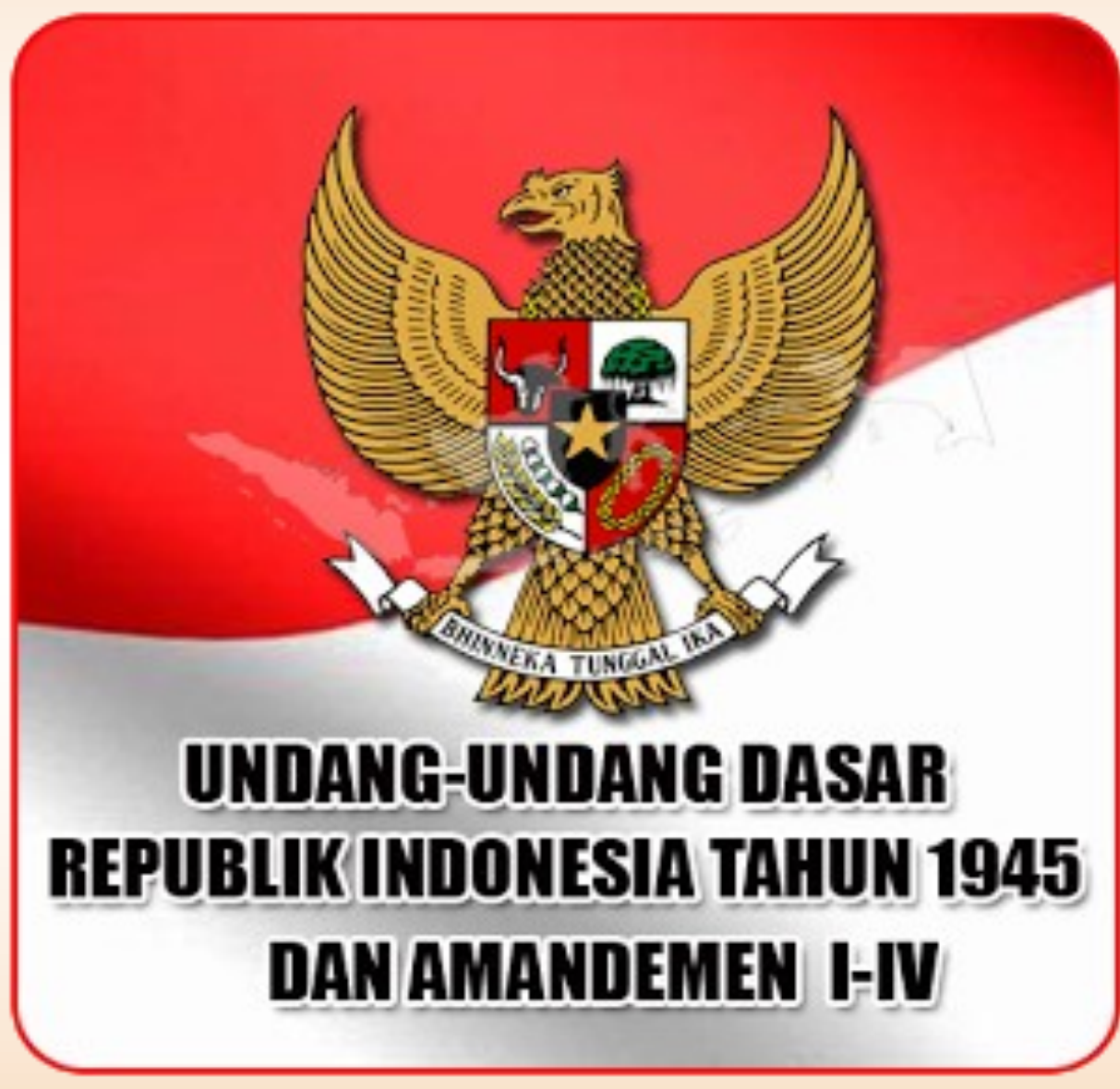

menekankan pada aspek normatif yang bermuatan kepentingan jangka pendek dengan melupakan aspek sosiologis dan filosofis. Agar lebih ideal, perubahan komprehensif UUD 1945 seyogianya mengandung tiga nilainilai positif yang amat mendasar, yaitu paradigma baru, substansi barn yang mengandung kerangka fakir perbaikan negara hukum dan demokrasi, -serta paradigma checks and balances terhadap perlunya akuntabilitas publik dalam menciptakan Good Govern-

\section{ance." (Maas, 2012: 9).}

Oleh karena itu, perlu adanya upaya serta gagasan baru dalam sistem ketatanegaraan Indonesia, untuk menghadirkan peranan berupa aspirasi masyarakat dalam amandemen UUD 1945 yang akan datang.

Menanggapi hal tersebut, beberapa kalangan mengusulkan penambahan kewenangan Mahkamah Konstitusi untuk menguji amandemen UUD 1945 sebelum disahkan (Judicial 
Preview). Agar, hasil amandemen UUD selanjutnya tidak sarat akan kepentingan politik belaka, akan tetapi kental dengan kepentingan bangsa. Mengingat bahwa pembentuk UUD 1945 yaitu Majelis Permusyawaratan Rakyat tidak lagi memiliki kepercayaan rakyat secara utuh karena berbagai polemik di dalamnya.

\section{Zulqodri Anand mengatakan bahwa:}

"Ketika arus gerakan reformasi berhasil menumbangkan sakralisasi UUD 1945, banyak pula tuntutan dari arus bawah untuk memperbaiki UUD agar ia mampu membangun sitem politik dan ketatanegaraan yang demokratis. Gagasan ini memiliki urgensi yang sangat kuat, mengingat dalam tiga periode sistem politik ternyata di Indonesia tak pernah lahir sistem politik yang demokratis sehingga selalu menimbulkan korupsi dalam berbagai bidang kehidupan" (Anand, 2013: 277)

Majelis Permusyawaratan Rakyat sebagai lembaga pembentuk UUD 1945, merupakan lembaga tinggi negara juga salah satu lembaga politik Indonesia. Anggota MPR berasal dari dua lembaga tinggi negara lainnya yaitu DPR dan DPD yang keduanya juga merupakan lembaga politik Indonesia. Karenanya, dapat dipastikan bahwa substansi dalam amandemen UUD 1945 yang akan disusun oleh MPR, didominasi oleh berbagai kebijakan politik. Karena empat amandemen UUD 1945 sebelumnya telah membuktikan, bahwa dalam amandemen UUD 1945 tersebut, suara masyarakat dikalahkan oleh politik para penguasa. Sehingga, demi melahirkan amandemen UUD 1945 yang sesuai dengan Pancasila, pertimbanganpertimbangan politik tersebut harus diimbangi dengan kewenangan Mahkamah Konstitusi, untuk menguji amandemen dengan pertimbangan hukum ketatanegaraan serta pertimbangan lainnya, agar hasil amandemen UUD 1945 selanjutnya dapat sejalan dengan cita-cita dan jati diri bangsa Negara Kesatuan Republik Indonesia.

UUD 1945 ialah milik seluruh bangsa Indonesia. Karenanya, dalam membentuk UUD 1945 harus melibatkan seluruh bangsa. UUD 1945 dapat diibaratkan sebagai jantung sebuah negara Indonesia. Sehingga, apabila UUD diubah, maka ketatanegaran negara, stabilitas ekonomi, politik, sosial dan budaya bangsa akan turut berubah pula. Oleh karena itu, perubahan tersebut harus tetap terarah sesuai dengan kebutuhan hukum masyarakat atas sebuah pondasi, bukan malah menjadi kuda tunggangan para politisi.

Peran Mahkamah Konstitusi sebagai pengawal konstitusi (the guardian of constitution), penafsir akhir konstitusi (the final interpreter of constitution), pengawal demokrasi (the guardian of democracy), pelindung hakhak konstitusional warga negara (the protector of citizen's constitutional rights), dan pelindung hak-hak asasi manusia (the protector of human rights), mewajibkannya menjaga kemurnian serta keluhuran UUD 1945 sebagai norma teragung dalam hirarki perundang-undangan Indonesia. Sehingga, bila mana amandemen UUD 1945 justru menghadirkan ketentuan baru yang apancasilais atau mengubah kausul yang tidak dapat diubah dalam UUD, maka sejatinya amandemen tersebut akan merusak hakikat dari konstitusi itu sendiri.

Hal tersebut tentu tidak boleh dibiarkan. Dengan demikian, perlu ada upaya untuk memastikan, bahwa hasil amandemen yang akan disahkan tidak menciptakan kemunduran hukum bangsa, karena sebagaimana yang diungkapkan oleh Prof. Sri Sumantri, bahwa amandemen Undang-Undang Dasar 1945 yang telah dilakukan sebanyak empat kali masih memiliki banyak kekurangan, karena memang proses perubahannya belum tutas. Sehingga dalam hal ini kewenangan MK untuk menguji amandemen UUD 1945 dianggap sebagai upaya untuk untuk melengkapi serangkaian proses perubahan tersebut, agar hasil amandemen UUD 1945 berdasarkan pada asas yang pancasilais, humanis, dan demokratis.

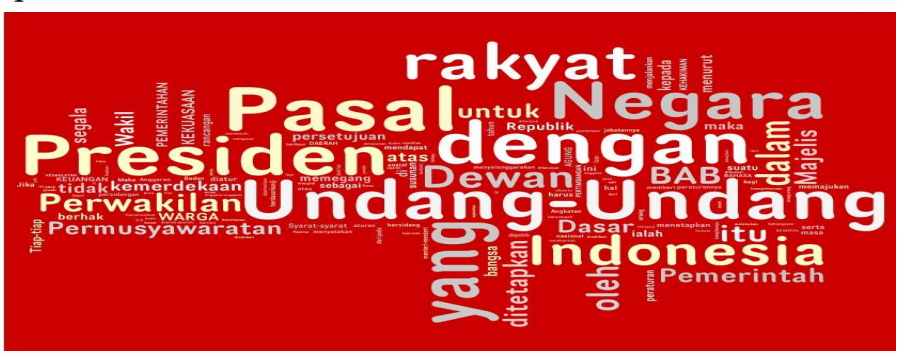

\section{Pustaka Acuan:}

*Penulis adalah anggota Perhimpunan Mahasiswa Hukum Indonesia (PERMAHI) dan Anggota Moot Court Community (MCC) FSH UIN Jakarta.

Maas, Marwan. "Menggagas Perubahan Kelima Undangundang Dasar 1945." Jurnal Hukum PRIORIS. vol. 3, no. 1 (2012).

Anand, Zulqadri. "Implikasi Perubahan Undang-Undang Dasar 1945 Terhadap Sistem Ketatanegaraan Indonesia." Fiat Justitia Jurnal Ilmu Hukum. vol. 7, no. 1 (2013).

Yunus, Nur Rohim, "Aktualisasi Demokrasi Pancasila Dalam Kehidupan Berbangsa dan Bernegara," dalam Jurnal Sosio Didaktika: Social Science Education Journal, vol. 2, no.2, (2015).

'Adalah; Buletin Hukum dan Keadilan merupakan berkala ilmiah yang diterbitkan oleh Pusat Studi Konstitusi dan Legislasi Nasional (POSKO-LEGNAS), Fakultas Syariah dan Hukum UIN Syarif Hidayatullah Jakarta.

Penasehat: Prof. Dr. H. Abdul Ghani Abdullah, SH., Prof. Dr. H. A Salman Maggalatung, SH., MH. Pemimpin Redaktur: Indra Rahmatullah, Tim Redaktur: Nur Rohim Yunus, Fathuddin, Mara Sutan Rambe, Muhammad Ishar Helmi, Erwin Hikmatiar. Penyunting: Indah Furba, Hasin Abdullah. Setting \& Layout: Siti Anisaul Kamilah. 